\title{
Do Lyrics Objectify Women?
}

\author{
Alyssa Klinksiek \\ Radford University (graduate student) \\ Timothy L. Channell \\ Radford University \\ This paper was presented at the 2018 International Summit of the \\ Music \& Entertainment Industry Educators Association \\ March 22-24, 2018
}

$\underline{\text { https://doi.org/10.25101/18.14 }}$

\section{Abstract}

Popular music should empower women as individuals with lyrics that recognize them as equals to men. Further, music should contain positive messages that promote respect for women from men. This study examines the prevalence of female objectification in popular music media through a textual analysis of 100 songs from the 2012-2016 end-of-year lists of the Billboard Hot 100 and Hot Country Songs. Objectification, as this study's framework, is defined as the depersonalization of an individual with an emphasis on their instrumentality (Loughnan, Haslam, Murnane, Vaes, Reynolds, and Suitner 2010). According to Gervais and Eagan (2017), women often face objectification from men and themselves in daily life through objectifying gazes and appearance commentary. Various studies have shown that female objectification leads to depression, anxiety, disordered eating, decreased intellectual performance, and internal motivation. This study takes five objectifying categories to analyze the text: objectifying gaze, appearance commentary, sex as a main priority, women portrayed as a sexual possession, and women portrayed as subordinate. This session will discuss the analysis and research findings.

\section{References}

Gervais, Sarah J., and Sarah Eagan. "Sexual objectification: The common thread connecting the myriad forms of sexual violence against women." American Journal of Orthopsychiatry 87, no. 3 (2017): 226-232. https:// doi.org/10.1037/ort0000257.

Loughnan, Steve, Nick Haslam, Tess Murnane, Jeroen Vaes, Catherine Reynolds, and Caterina Suitner. "Objectification leads to depersonalization: The denial of mind and moral concern to objectified others." European Journal of Social Psychology, 40, no. 5 (2010): 709-717. https://doi.org/10.1002/ejsp.755.
Alyssa Klinksiek graduated from Radford University in 2017 with a Bachelor of Music with a concentration in Music Business and is currently pursuing a Master of Arts in Music Leadership from Radford University with anticipation of a May 2018 graduation date. Klinksiek was the 2017 IBLA Scholar and traveled to Ragusa, Sicily, Italy to intern with the annual international music competition, IBLA Grand Prize. She is a passionate advocate for equality and hopes to use her research as a point for discussion and awareness of this is-

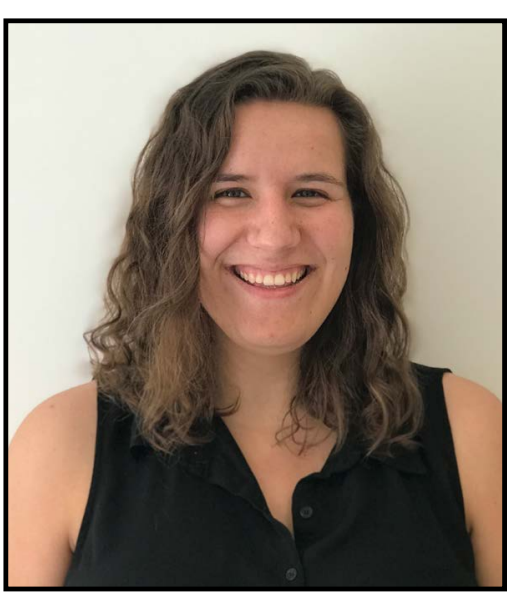
sue.

Timothy L. "Tim" Channell, Radford University Associate Professor and Music Business Program Director, has over thirty years of experience as a music educator, arts administrator, fundraiser, and in concert promotion. Dr. Channell has worked to bring nationally recognized performers to various concert venues. He has performed on or produced multiple recordings and has been very involved in working to raise capital support, market, promote, and develop relationships for various constituencies. Additionally, he has vast experience in event planning, contract negotiation, and budget

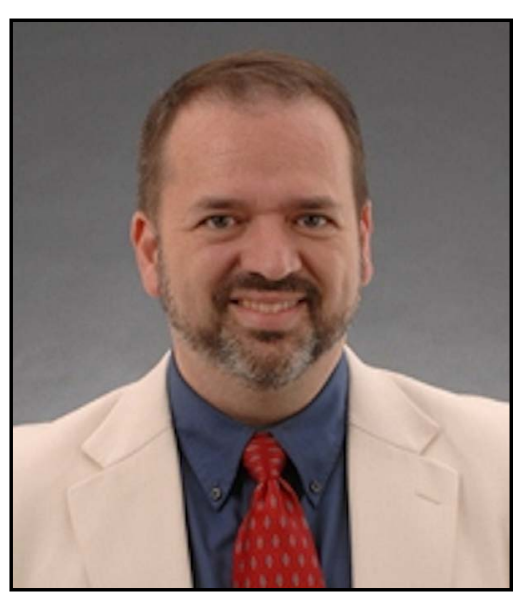


development, and has presented numerous workshops on fundraising throughout the east coast. Dr. Channell serves as the advisor to the RU-Grammy U., Radford Records (a lab-based student record label), Radford University $\mathrm{Mu}-$ sic Business Student Association, and a former co-advisor to Phi $\mathrm{Mu}$ Alpha Sinfonia Fraternity. He also oversees the Covington Center Performance Hall, providing leadership for performances and all audio and video recordings. Dr. Channell is a sought after adjudicator/clinician and is president of Channell Consulting Services, a firm providing specialized consulting for various arts organizations helping them better understand their current position and potential for financial and artistic growth. 


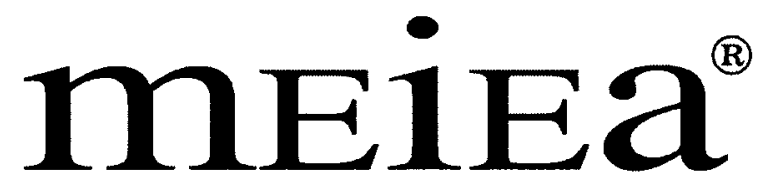

MUSIC \& ENTERTAINMENT INDUSTRY

EDUCATORS ASSOCIATION

\section{PROCEEDINGS OF THE \\ 2018 INTERNATIONAL SUMMIT}

OF THE

\section{MUSIC \& ENTERTAINMENT INDUSTRY EDUCATORS \\ ASSOCIATION}
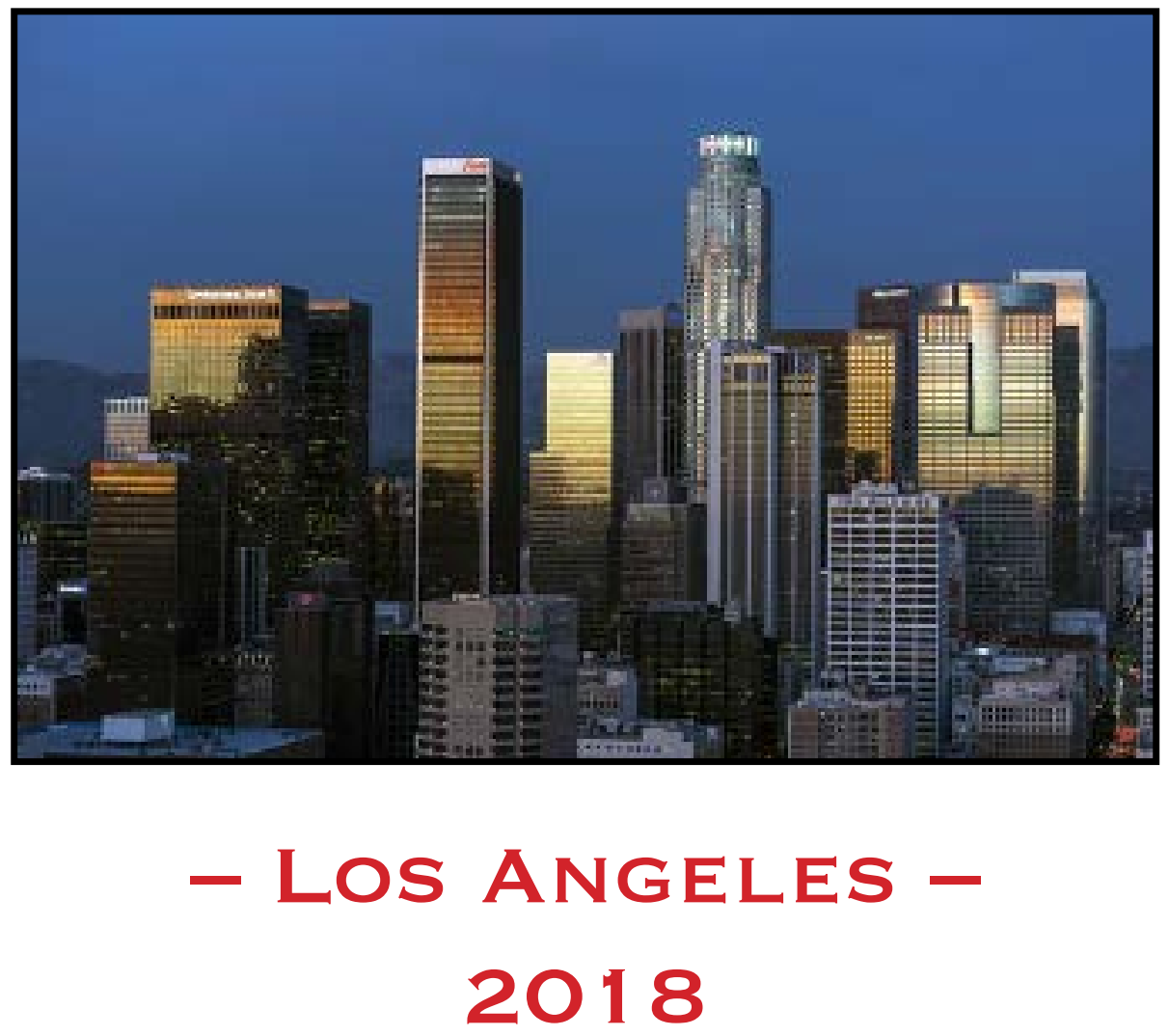

March 22 - 24, $2018 \cdot$ Embassy Suites by Hilton - Los Angeles/Glendale 